\title{
Nanomole per Hour
}

National Cancer Institute

\section{Source}

National Cancer Institute. Nanomole per Hour. NCI Thesaurus. Code C85753.

Nanomoles per hour. 